\title{
SELECTED SOCIOECONOMIC DETERMINANTS OF THE SIZE OF THE NONPROFIT SECTOR SERVING HOUSEHOLDS IN THE OECD COUNTRIES
}

\section{Jindřich Špička, Markéta Arltová, Petr Boukal ${ }^{*}$}

\begin{abstract}
The article investigates the differences in socioeconomic determinants of the size of the nonprofit sector serving households in the wealthy and less wealthy OECD countries. Based on panel data modelling of 22 wealthy OECD countries and 17 less wealthy OECD countries in the longterm period 2000-2014, authors revealed distinctive determinants of the size of the nonprofit sector serving households in the wealthy and less wealthy countries. The model identified GDP per capita, government health care expenditures per capita, number of refugees per hundred thousand inhabitants and unemployment rate as significant long-term determinants of the size of the nonprofit sector in the wealthy OECD countries. Alternatively, GDP per capita, age and educational structure are significant long-term determinants of the size of the nonprofit sector in the less wealthy OECD countries. Authors found opposing effect of GDP per capita on the size the nonprofit sector between the two groups of countries.
\end{abstract}

Keywords: econometric modelling, government failure, nonprofit sector serving households, wealth

JEL Classification: L31, H50

\section{Introduction}

The non-profit sector is both the same as and different from the private sector in many aspects. Supply, demand and competition can be distinguished both in the profit-making and nonprofit institutions. Originally, the theories of supply and demand were strictly separated (Hansmann, 1987) because the reasons why clients need to use services provided by nonprofit institutions are not related to the reasons why nonprofits are founded. However, more recent theories can see some relations between supply and demand in the nonprofit sector (Steinberg, 2006; Valentinov, 2009). According to Valentinov (2008), demand- and supply-side theoretical conceptions can always be used for a particular segment of nonprofits;

* Jindřich Špička, Faculty of Business Administration, University of Economics, Prague, Czech Republic (jindrich.spicka@vse.cz);

Markéta Arltová, Faculty of Informatics and Statistics, University of Economics, Prague, Czech Republic (marketa.arltova@vse.cz);

Petr Boukal, Faculty of Business Administration, University of Economics, Prague, Czech Republic (petr.boukal@vse.cz).

This article was funded by the institutional support for the long-term conceptual development of the research at University of Economics, Prague (Project Best Practice in Non-Governmental Organizations, VŠE IP309067) and by the Czech Science Foundation Project No. P402/12/G097 DYME - Dynamic Models in Economics. 
none of them explains the reasons for the considerable structural heterogeneity of entities in the non-profit sector.

The supply of a non-profit making organisation is influenced both by the volume of disposable sources, which can be used by the nonprofit (Grønbjerg, Paarlberg, 2001), and, for instance, by the efforts of the nonprofit institution to promote opinions, which applies mainly to religious non-profits (Roland, Valentinov, Buchenrieder, 2010). Disposable sources also include volunteers, who are willing to make considerable working efforts to accomplish the mission of a nonprofit (Gil-Lacruz, Marcuello, 2013; Clerkin, Swiss, 2013). The supply-side theory of nonprofits considers nonprofits as a tool for expressing altruism, ideological entrepreneurial activity, and professing social values (Valentinov, 2008). Nonprofits can receive grants from both the public and private sector. In both cases, the potential volume of grants can be influenced by the wealth of the society, private donors being partly displaced by government contributions to the nonprofit sector (O'Regan and Oster, 2002). However, no full displacement effect was proved because the public deems some services provided by nonprofit institutions to be unique and irreplaceable by any governmental activities (Weinblatt, 1992).

The theory of demand for services provided by the nonprofit sector is associated with the so-called theory of market failure and government failure. According to one of the theories of nonprofits (Pestoff, 1992), the private non-profit sector is in the middle of a triangle, whose points indicate commercial entities, government and households. The private nonprofit sector balances these three sectors and plays a vital role if imbalance is present. The position of a nonprofit institution with respect to companies, government and households, and the character of community activities are reflected in its mission and vision. The failure of one of the three points of the Pestoff triangle forms a precondition for a higher demand for nonprofit services, increasing the size of the nonprofit sector. In addition to the government failure theory based on the importance of the nonprofit sector as a substitute for the missing welfare services offered by the government, there is also a theory of interdependence, i.e. mutual interconnection (Lecy, van Slyke, 2013). According to that theory, the nonprofit services are neither a substitute nor a competitor to the governmental activities or public sector activities; they are rather their complement based on partnership and cooperation (Gazley, Brudney, 2007; Gazley, 2010).

The competition intensity is the third factor affecting the size of the nonprofit sector. In practice, Porter's five forces concept, which was originally developed for the profitmaking sector, can be used for a strategic analysis (Schwenger, Straub and Borzillo, 2014). A specific feature of nonprofit institutions is that entities providing financial means usually are not the recipients of provided services, which can lead to the inconsistency between the funding received by the nonprofit institution and the value created by the organisation (Gonzales et al., 2002).

Most of the empirical studies use secondary data and try to compare the size of the nonprofit sector on the regional or international level, and to identify key factors that affect the size. A regional analysis of determinants of the size of the nonprofit sector in the Spanish province of Catalonia was carried out by Marcuello (1998). Among other 
things, she summarised results of literary research, where she, like some other authors (BenNer and Van Hoomissen, 1991), divided welfare services into "trust goods" and "collective goods". The trust goods include club goods and mixed goods, which can be characterised by the information asymmetry between nonprofits and clients (e.g. education). Collective services (collective goods) include purely public goods and mixed goods characterised by non-excludability from consumption, with a significant non-rival component (e.g. nonprofits focusing on the protection of the environment, or the Salvation Army). The higher the income and the education level of the society, the lower the demand for trust services; on the other hand, there is a higher demand for collective services of nonprofits. If services of a nonprofit institution are burdened with information asymmetry towards clients, less educated and less fortunate people have to make more efforts to obtain additional information in order to use the services offered by the nonprofit institution. On the other hand, people with higher education are able to check the management of a nonprofit institution more effectively, which enables transparent non-profit institutions providing collective services to succeed in the market and attract donors.

Luksetich (2008) examined the relationship between the number of nonprofit institutions and government contributions to activities of nonprofit institutions (grants). Based on a statistical analysis of 190 randomly selected nonprofit institutions monitored in a time series, he validated the conclusions of former publications that the availability of government grant programmes is a very important determinant of the size of the nonprofit sector in a relevant country. In particular, it influences the number of large nonprofit institutions. However, the author pointed out that not all non-profit institutions have the same funding structure. Some nonprofits, e.g. social care organisations or hospitals, are strongly dependent on financial contributions from public resources or grant programmes; other nonprofit institutions are more self-sufficient and are partly funded from their own economic activity. Thus, the relation between government grant programmes and the number of nonprofit institutions cannot be applied generally to the entire nonprofit sector.

Pryor (2009) examined the determinants of the size of the nonprofit sector in 25 countries. Measures of the size of the nonprofit sector included the proportion of the nonprofit staff to economically active inhabitants, and the nonprofit sector expenses related to the gross domestic product (GDP). The author identified that the size of the nonprofit sector depends on GDP per capita and on the income disparity of inhabitants. Moreover, he proved the significant role of the government as a factor influencing the size of the nonprofit sector. In countries with historically centrally planned economies, the size of the nonprofit sector is smaller than in countries with a democratic history. The nonprofit sector is also more extensive in countries, where the government intentionally leaves some welfare activities up to nonprofits because they can provide those services better than the government.

Pryor was followed by Pevcin (2012), who examined the differences in the size of the nonprofit sector in 38 countries selected according to available data. He used the same criteria for defining the size of the nonprofit sector as Pryor (2009). The use of relative indicators evaluating the size of the nonprofit sector with respect to the national economy can be disputed in the case of both these authors, as the relative size of the nonprofit sector can be 
strongly affected by the size of other sectors of the economy, the proportion of the nonprofit sector being usually marginal, amounting to a few percentage points. The absolute size of the nonprofit sector related to the number of inhabitants is a more appropriate indicator, which also ensures the international comparability and separation of the majority sectors of the economy from the nonprofit sector. In addition, the "final consumption expenditure of nonprofit institutions serving households" indicator quantifies only a part of the nonprofit sector, which, however, Pryor admits, but he applies the results to the whole nonprofit sector. According to Pevcin, the most important determinants of the size of the nonprofit sector include the wealth of the society (direct proportion) and income disparity of inhabitants (direct proportion), which validates the theory of nonprofit institutions based on the supply of services, influenced by the wealth of the relevant country. Language differences resulting from the cultural history of the nation is the third most important determinant of the size of the nonprofit sector.

The international comparison of the size of the nonprofit sector was also conducted by Matsunaga, Yamauchi and Okuyama (2010). They based their work on Salomon et al. (2000), and empirically verified if the effect of the government failure influences the size of the nonprofit sector. Based on the analysis of the model of fixed effects in a data panel consisting of 22 countries, they found that the government failure theory is a rational substantiation of the variability of the nonprofit sector among countries. They selected the proportion of the number of people working in the nonprofit sector (the full-timeemployee equivalent) to the total number of workers (non-agricultural) in the society as an indicator for the assessment of the size of the nonprofit sector. They tested the explanatory variables, identifying the volume of government expenditures on education and health care and the income level as the important determinants of the size of the nonprofit sector. In addition, they found out that democracy and political freedom have an adverse effect on the size of the nonprofit sector, which contradicted their expectations.

Particularly empirical studies indicate possible determinants of the size of the nonprofit sector. This article extends the existing empirical studies of view coming from different socioeconomic level between wealthier and less wealthy countries. Authors have usually identified only determinants of the size of the nonprofit sector between countries. However, they have not followed whether the same determinants act similarly in the wealthier and less wealthy countries. Authors suggest that economic differences between countries not only affect the size of the nonprofit sector, as it has been shown so far, but the differences between the two groups of countries cause the different models of financing nonprofit organizations, which, inter alia, results from historical context and traditional behavioural models the country's population as well as from different attractiveness of countries in terms of entry of new nonprofit organizations.

This article should answer the question which macroeconomic and social indicators significantly affect the size of the nonprofit sector in wealthier and less wealthy countries? The research is limited to the nonprofit sector serving households in selected countries of the Organization for Economic Cooperation and Development (OECD) with available data. So, it is possible to generalize results only on this segment of the nonprofit sector 
and the OECD countries. Based on the quantitative research of secondary data, the aim of the article is to identify the determinants of the size of the nonprofit sector serving households, to determine the direction and intensity of their influence on the size of the nonprofit sector serving households in OECD countries. The results are discussed. There are also limits of the research in the conclusion.

\section{Methodology}

The indicator "Final consumption expenditure of nonprofit institutions serving households per capita" (NGO) is a proxy variable of the size of the nonprofit sector serving households. To ensure comparability over time and between countries, we used values in USD per capita, constant prices (2010) and purchasing power parity.

Document "European System of Accounts ESA 2010" (EC, 2013) contains a definition of nonprofit institutions serving households and content of final consumption expenditure of nonprofit institutions serving households. "The nonprofit institutions serving households (NPISHs) sector (S.15) consists of nonprofit institutions which are separate legal entities, which serve households and which are private non-market producers. Their principal resources are voluntary contributions in cash or in kind from households in their capacity as consumers, from payments made by general government and from property income."

A group of explanatory variables was selected based on supply-side and demand-side theories of the nonprofit sector.

The supply-side theory of nonprofit sustainability is represented by two explanatory variables.

- GDP: The Gross domestic product per capita (GDP) reflects the economic level of the country. The previous research (Pevcin, 2012; Pryor, 2012) has shown that GDP significantly positively affects the size of the non-profit sector. GDP is expressed in US dollars per capita in purchasing power parity, and at constant prices of 2010 .

- $\quad E D U C(\%)$ : The share of population with tertiary education relative to total population in the country. It represents the level of education in the country. The hypothesis is that the higher the education level of the population, the greater the altruistic behaviour of the society as well as a dimension of nonprofit organizations in the country.

The demand-side theory of nonprofit sustainability depicts the need for services of the nonprofit organizations serving households which provide a variety of social services such as housing, health care, culture, education, social care, social protection and faith involvement. So, authors considered following representatives of the variables.

- $\quad A G E(\%)$ : The Old-age dependency ratio, expressed as a proportion of people aged 65+ to the population aged 15-64. The hypothesis is that the higher the proportion of elderly people in the economically active population, the greater a burden on the country's social system. Thus, it gives more space to the nonprofit organizations. 
- The "Human Development Index" $(H D I)$ is a multidimensional indicator of living standards in the country. The HDI is the geometric mean of the indices which express each of the three dimensions - long and healthy life, access to education and standard of living. However, HDI might be not suitable for one of the independent variable, since HDI contains various elements, some of them may be included in other independent variables. Finally, the algorithm excluded this variable.

- HEALTH: The Government expenditures on health care per capita, expressed in US dollars per capita in purchasing power parity, and at constant prices of 2010. The hypothesis is that the lower the government spending on health care, the greater the need for NGOs to cast that role of the government (government failure theory). However, since the nonprofit organizations serving households have been supported by payments made by general government, there could be a positive relationship where the government supports both health care and social care in the NGOs.

- $\quad$ LIFEEXP: Life expectancy at birth refers to the average number of years a new-born is expected to live if mortality patterns at the time of its birth remain constant in the future. The hypothesis is that increasing life expectancy goes hand in hand with improving living and economic conditions of the elderly which is supported by the development of the non-profit sector.

- $\quad$ REFUG: The number of refugees per hundred thousand inhabitants. The hypothesis is that the higher is a relative number of refugees in the country, the greater is the need for social services provided through NGOs. This issue has been more topical in recent years.

- $\quad$ UNEMPL (\%): The annual unemployment rate of the population between 15 and 64 years old. The hypothesis is that the higher the unemployment, the greater the demand for the social services of the nonprofit sector.

The dataset contains annual time series data in the period 2000-2014. The data comes from the official databases of the Organization for Economic Co-operation and Development (NGO, AGE, EDUC, GDP, HEALTH, UNEMPL; OECD, 2016), the World Health Organization (LIFEEXP; WHO, 2016), the World Bank (REFUG; WB, 2016) and the United Nations Development Programme (HDI; UNDP, 2016).

Authors investigated the relationships though macro-panel data, i.e. time series of macroeconomic indicators for the two groups of countries. In our case, we have time series of socio-economic indicators in the period 2000-2014 for 39 OECD countries (OECD, 2016), which were divided by the size of GDP per capita in two groups - the group of wealthier countries and the group of less wealthy countries. The threshold was GDP per capita at the level 28 thousand USD expressed in in purchasing power parity in the last five years of the period. Eurostat divides regions relatively "wealthy" and relatively "less wealthy" according to the average GDP per capita in purchasing power standards (PPS). In 2014, this threshold was 27.5 thousand USD in purchasing power parity which roughly corresponds to our threshold (Eurostat).

The group of wealthier countries includes 22 countries (in alphabetical order): Austria, Belgium, Canada, Cyprus, Denmark, Finland, France, Germany, Iceland, Ireland, Italy, 
Japan, Luxembourg, the Netherlands, New Zealand, Norway, South Korea, Spain, Sweden, Switzerland, the United Kingdom and the United States. A group of less wealthy countries includes 17 countries (in alphabetical order): Bulgaria, Croatia, the Czech Republic, Estonia, Greece, Hungary, Israel, Latvia, Lithuania, Malta, Mexico, Poland, Portugal, Romania, Russian Federation, Slovakia and Slovenia.

Table 1 contains basic summary statistics of all explanatory and response variables.

Table 1 | Summary Statistics of Variables in Two Groups of OECD Countries

\begin{tabular}{|l|r|r|r|r|r|r|r|r|r|r|}
\hline & \multicolumn{4}{|c|}{ Wealthier countries $\left(n_{1}=330\right)$} & \multicolumn{3}{c|}{ Less wealthy countries $\left(n_{2}=255\right)$} \\
\cline { 2 - 12 } & Mean & Median & \multicolumn{1}{|c|}{ Max } & \multicolumn{1}{c|}{ Min. } & \multicolumn{1}{c|}{ SD } & Mean & Median & \multicolumn{1}{c|}{ Max } & Min. & SD \\
\hline NGO & 621.9 & 610.5 & 1431.2 & 165.3 & 278.7 & 242.4 & 212.6 & 639.6 & 22.0 & 144.6 \\
\hline GDP & $41,065.8$ & $38,920.8$ & $90,846.8$ & $18,868.1$ & $11,723.5$ & $20,978.1$ & $21,572.2$ & $32,358.8$ & $7,813.9$ & $5,562.2$ \\
\hline AGE & 23.2 & 23.2 & 40.7 & 10.1 & 4.9 & 21.8 & 22.7 & 31.6 & 7.6 & 4.9 \\
\hline EDUC & 31.3 & 31.7 & 51.5 & 11.4 & 7.7 & 24.8 & 22.5 & 56.3 & 7.5 & 11.2 \\
\hline HDI & 88.4 & 88.6 & 94.4 & 80.0 & 2.6 & 80.5 & 80.9 & 89.4 & 69.9 & 4.4 \\
\hline HEALTH & $2,830.8$ & $2,802.8$ & $5,882.9$ & 429.9 & $1,039.8$ & $1,056.2$ & $1,049.5$ & $2,133.7$ & 249.7 & 462.4 \\
\hline LIFEEXP & 80.0 & 80.1 & 83.5 & 76.0 & 1.5 & 75.2 & 75.2 & 82.2 & 64.6 & 3.7 \\
\hline REFUG & 359.3 & 218.8 & $1,774.2$ & 0.0 & 357.0 & 89.2 & 13.8 & $2,350.9$ & 0.3 & 287.9 \\
\hline UNEMPL & 6.6 & 5.7 & 26.2 & 1.8 & 3.4 & 10.0 & 8.6 & 27.7 & 2.6 & 4.5 \\
\hline
\end{tabular}

Source: data OECD, own calculation

Wealthier countries have significantly higher final consumption expenditure of NPISHs due to higher financial possibilities resulting from GDP per capita. Higher social and economic level of wealthier countries towards less wealthy ones is documented by significantly higher proportion of university graduates, higher government expenditure on health care, higher human development index and higher life expectancy index. Higher standard of living in wealthier countries is also reflected in the higher refugees' interest in these countries.

Authors collected all indicators for all above mentioned countries in all monitored years. So, the analysis is based on strongly balanced panels which are characterized by a reasonably long length of time series $T=15$ and the number of countries $N_{1}=22$ and $N_{2}=17$. This fact allows the use of panel data regression that enables to test spurious regression and panel cointegration (e.g. Phillips, Moon, 1999 and 2000; Baltagi, Fomby and Hill, 2000; Arlt, Arltová, 2005).

The basic prerequisite for the existence of a panel cointegration relationship is a nonstationarity of time series. First, it is necessary to test whether the analysed panels contain unit roots. If time series are not nonstationary, there cannot be a cointegration relationship between them. Similarly, the cointegration relationship cannot be between nonstationary and the stationary panel. 
Authors used following unit root tests: LLC test (Levin and Lin, 1992; Levin, Lin, and Chu, 2002), IPS test (Im, Pesaran and Shin, 2003), Breitung test (Breitung, 2000), Fisher-ADF test and Fisher-PP test (Maddala and Wu, 1999) which were, in some cases, accompanied by a subjective assessment correlogram. Appendix 1 introduces results of the unit root tests for the group of wealthier countries. Appendix 2 contains results of the unit root test for less wealthy countries.

Since the LLC test, Fisher-ADF test and Fisher-PP test indicate that the panels in some of the time series contain unit roots, it is possible to consider panels as heterogeneous. The question of dynamic heterogeneous panels was described by Pesaran (2015) and authors follow it.

Simple linear panel data model with exogenous variables can be written in the form

$$
y_{i t}=\alpha_{i}+\boldsymbol{\beta}^{\prime} \boldsymbol{x}_{i t}+u_{i t} \text {. }
$$

This static model is usually not enough in the economic area because the economic relationships are naturally dynamic over time. It is therefore necessary to extend the model to the ARDL model $(p, q, \ldots, q)$ :

$$
y_{i t}=\alpha_{i}+\sum_{j=1}^{p} \lambda_{i j} y_{i, t-j}+\sum_{j=0}^{q} \boldsymbol{\delta}_{i j}^{\prime} \boldsymbol{x}_{i, t-j}+u_{i t}, \quad i=1, \ldots, N, j=1, \ldots, T
$$

where $\boldsymbol{x}_{i t}$ is a $k$-dimensional vector of explanatory variables for group $i, \alpha_{i}$ represent the coefficients of the lagged dependent variables (the fixed-effects), $\lambda_{i j}$ are scalars, and $\boldsymbol{\delta}_{i j}$ are $k$-dimensional coefficient vectors, $u_{i t}$ are the $\operatorname{iid}\left(0, \sigma_{u_{i}}^{2}\right)$ across $i$ and $t$, and are distributed independently of the regressors $\boldsymbol{x}_{i t}$.

The ARDL model reflects just the short-term relationships. In order to add longterm relationships, it is necessary to convert the model into the EC model. The error correction of the above ARDL model is:

$$
\Delta y_{i t}=\alpha_{i}+\phi_{i} y_{i, t-1}+\boldsymbol{\beta}_{i j}^{\prime} \boldsymbol{x}_{i t}+\sum_{j=1}^{p-1} \lambda_{i j}^{*} \Delta y_{i, t-j}+\sum_{j=0}^{q-1} \boldsymbol{\delta}_{i j}^{\prime *} \Delta \boldsymbol{x}_{i, t-j+} u_{i t}
$$

where

$$
\begin{aligned}
& \phi_{i}=-\left(1-\sum_{j=1}^{p} \lambda_{i j}\right), \boldsymbol{\beta}_{i}=\sum_{j=0}^{q} \boldsymbol{\delta}_{i j}, \lambda_{i j}^{*}=-\sum_{m=j+1}^{p} \lambda_{i m}, j=1,2, \ldots, p-1 \text { a } \boldsymbol{\delta}_{i j}^{*}=-\sum_{m=j+1}^{q} \boldsymbol{\delta}_{i m}, \\
& j=1,2, \ldots, q-1 .
\end{aligned}
$$

In our case, we have many time series for each indicator. Therefore, the model (3) can be adjusted in form:

$$
\Delta \boldsymbol{y}_{i .}=\alpha_{i} \boldsymbol{\tau}_{T}+\phi_{i} \boldsymbol{y}_{i .,-1}+\boldsymbol{\beta}_{i} \boldsymbol{X}_{i .}+\sum_{j=1}^{p-1} \lambda_{i j}^{*} \Delta y_{i .,-j}+\sum_{j=0}^{q-1} \boldsymbol{\delta}_{i j}^{*} \Delta \boldsymbol{X}_{i .,-j}+\boldsymbol{u}_{i .},
$$

for $i=1,2, \ldots, N$, where $\boldsymbol{\tau}_{T}$ is a $T$ x 1 vector of ones, $\boldsymbol{y}_{i,-, j}$ and $\boldsymbol{X}_{i,-j}$ are $j$-period lagged values of $\boldsymbol{y}_{i .}$ and $\boldsymbol{X}_{i,}, \Delta \boldsymbol{y}_{i .}=\boldsymbol{y}_{i .}-\boldsymbol{y}_{i,-1}, \Delta \boldsymbol{X}_{i .}=\boldsymbol{X}_{i .}-\boldsymbol{X}_{i,-,-1}, \Delta \boldsymbol{y}_{i,-, j}$ and $\Delta \boldsymbol{X}_{i,-, j}$ are $j$-period lagged values of $\Delta \boldsymbol{y}_{i .}$ and $\Delta \boldsymbol{X}_{i}$. 
When considering a situation where $y_{i t}$ a $\boldsymbol{x}_{i t}$ for each $i=1,2, \ldots, N$ are of type $\mathrm{I}(1)$, then, under the assumption of roots of the polynomial $\sum_{j=1}^{p} \lambda_{i j} z^{j}=0$, fall outside the unit circle, model (2) is stable. This condition ensures that $\phi_{i}<0$, and that there exists a long-run relationship between $y_{i t}$ and $\boldsymbol{x}_{i t}$ defined by

$$
y_{i t}=\boldsymbol{\theta}_{i} \boldsymbol{x}_{i t}+\eta_{i t}, \quad i=1,2, \ldots, N,
$$

where $\eta_{i t}$ is the stationary process, and $\boldsymbol{\theta}_{i}=-\boldsymbol{\beta}_{i} / \phi_{i}$ are the long-run coefficients on $\boldsymbol{X}_{i .}$.

\section{Results}

\subsection{Wealthier countries}

In case of wealthier countries (Table 1) it is evident that all variables except LIFEEXP and UNEMPL are of type I(1). In the first step (1), the presence of the spurious regression or cointegration panel regression was tested. Panels are cointegrated when residuals $u_{i t}$ are stationary. Alternatively, there is the spurious panel regression relationship when residuals $u_{i t}$ are non-stationary I(1).

The Kao cointegration test $(\mathrm{Kao}, 1999)$ shows $\left(t_{\mathrm{ADF}}=2.0919\right.$, Prob. $\left.=0.0182\right)$ that residuals of the static panel model ( 1 ) are stationary $\mathrm{I}(0)$. It means that there is not the spurious regression in the model. The problem of autocorrelation (Cross-section dependence test: Breusch-Pagan LM Stat. $=856.0291$, Prob. $=0.0000)$ was dealt through model dynamization, i.e. by model estimation in the form of ARDL (2).

It is possible to express the estimated model in the following form:

$$
\begin{gathered}
\widehat{N G O}_{t}=1.01109 N G O_{t-1}+0.00098 G D P_{t}-0.00852 \text { HEALTH }_{t-1}- \\
(0.0061) \quad(0.00018) \\
-0.00973 \text { REFUG }_{t}-1.20075 \text { UNEMPL }_{t-1}, \\
(0.00426)
\end{gathered}
$$

The regression formula indicates that the size of the nonprofit sector in current year directly depends on the size of the nonprofit sector in the previous year as well as on GDP in the current year. Alternatively, the size of the nonprofit sector in current year indirectly depends on government health care expenditures per capita in previous year, on the number of refugees per hundred thousand of inhabitants in the current year and on the unemployment rate in the previous year. The model excluded the age structure (old dependency ratio), the share of tertiary educated people in the country, the Human Development Index and the life expectancy at birth.

Diagnostic control of the model indicates that non-systematic component of the panel has no autocorrelation (Cross-section dependence test: Breusch-Pagan LM Stat. $=255.7617$, Prob. $=0.1263), R^{2}=0.9933$.

However, the model (6) does not provide sufficient information because the ARDL model identifies only the short-term relationships. Since the Kao's test of panel cointe- 
gration revealed that there are both short-term and long-term relationships, it is possible to reformulate the model into the form (4) and get the EC model.

$$
\begin{gathered}
\Delta \widehat{N G O}_{t}=0.00098 \Delta G D P_{t}-0.00973 \Delta R E F U G_{t}+ \\
+0.0111\left[N G O_{t-1}+0.0887 G D P_{t-1}-0.7678 \text { HEALTH }_{t-1}-0.8772 R E F U G_{t-1}-\right. \\
\left.-108.244 U N E M P L_{t-1}\right],
\end{gathered}
$$

where the parameter $\phi=0.0111$ provides information about the speed at which the system responds to balance deviation. The long-term relationship can be expressed as follows.

$$
\widehat{N G O}_{t}=-0.0887 G D P_{t}+0.7678 \text { HEALTH }_{t}+0.8772 \text { REFUG }_{t}+108.244 U N E M P L_{t} .
$$

The long-term multiplicators show that the increase of GDP per capita by 1 USD decreases the size of nonprofit institutions serving households per capita by 0.09 USD. The increase of the government health care expenditures per capita by 1 USD increases the size of the nonprofit sector serving households per capita by 0.77 USD. When the number of refugees per hundred thousand of inhabitants increases by 1 person, the size of the nonprofit sector serving households per capita increases by 0.88 USD. Finally, higher unemployment rate by 1 percentage point helps to increase the size of the nonprofit sector serving households per capita by 108.2 USD. The results are discussed in the separate chapter.

\subsection{Less wealthy countries}

The process of model generation and diagnostics is the same as in case of the wealthier countries because all panels except UNEMPL (Appendix 1) are nonstationary. Moreover, the Kao's cointegration test indicates $\left(t_{\mathrm{ADF}}=-1.4592\right.$, Prob. $\left.=0.0422\right)$ that there is cointegration between panels. The autocorrelation identified through the cross-section dependence test (Breusch-Pagan LM Stat. $=552.5727$, Prob. $=0.0000)$ was removed by the following ARDL model.

$$
\begin{gathered}
\widehat{N G O}_{t}=1.01353 N G O_{t-1}+0.00643 G D P_{t}-0.00671 G D P_{t-1}+0.47984 A G E_{t-1}- \\
(0.0106) \quad(0.00103) \quad(0.00105) \\
-0.19535 E D U C_{t-1} \\
(0.09444) .
\end{gathered}
$$

The short-term relationships in the formula (9) shows that the final consumption expenditure of NPISHs in the current year directly depends on the final consumption expenditure of NPISHs in the previous year, on GDP per capita in the current year and on the age structure (old dependency ratio) in the previous year. Alternatively, the final consumption expenditure of NPISHs in the current year indirectly depends on GDP in the previous year and the share of tertiary educated people in the country in the previous year. The model excluded the Human Development Index, the government health care expenditures per capita, the life expectancy at birth, the number of refugees per hundred thousand of inhabitants in the country and the unemployment rate. 
Diagnostic control of the model indicates that non-systematic component of the panel has no autocorrelation (Cross-section dependence test: Breusch-Pagan LM Stat. = 158.1034, Prob. $=0.0945), R^{2}=0.9876$.

After transformation of model (9) into the EC formula, we get the model estimation:

$$
\begin{aligned}
& \Delta \widehat{N G O}_{t}=0.00643 \Delta G D P_{t}+0.0135\left[N G O_{t-1}-0.4955 G D P_{t-1}+\right. \\
&+\left.35.457 A G E_{t-1}-14.435 E D U C_{t-1}\right]
\end{aligned}
$$

where the parameter $\phi=0.0135$ represents the speed at which the system responds to balance deviation from equilibrium. The long-term relationship can be expressed in the following equation:

$$
\widehat{N G O}_{t}=0.4955 G D P_{t}-35.457 A G E_{t}+14.435 E D U C_{t} .
$$

The long-term multiplicators show that the increase of GDP per capita by 1 USD increases the size of nonprofit institutions serving households per capita by 0.5 USD. The increase of the share of seniors (64+) to economically active population (15-64 years old) by one unit decreases the size of the nonprofit sector serving households per capita by 35.46 USD. Finally, higher share of tertiary educated people in the country by 1 percentage point increases the size of the nonprofit sector serving households per capita by 14.435 USD. The results are discussed in the separate chapter.

\section{Discussion}

The econometric models show that the dimension of the nonprofit sector serving households is affected by different socio-economic factors in wealthier countries compared to the group of less wealthy countries. Table 2 compares the results for both groups of countries. Moreover, there is a different direction of effect of GDP per capita size on the nonprofit sector serving households between the two groups of countries. The differences have not been detected by other authors. So, the question is whether differences in the explanatory variables are reasonable.

Table 2 | Summary of the Long-Term Socioeconomic Determinants

\begin{tabular}{|l|c|}
\hline Group of countries & \multicolumn{1}{|c|}{ Long-term determinants } \\
\hline Wealthier Countries & $\widehat{N G O}_{t}=-0.0887 G D P_{t}+0.7678 H E A L T H_{t}+0.8772$ REFUG $_{t}+108.244 U N E M P L_{t}$ \\
\hline Less Wealthy Countries & $\widehat{N G O}_{t}=0.4955 G D P_{t}-35.457 A G E_{t}+14.435 E D U C_{t}$ \\
\hline
\end{tabular}

Source: own calculation

\subsection{Wealthier countries}

It was found that the final consumption expenditure of nonprofit institutions serving households per capita is in inverse proportion to GDP per capita in the relevant country. The proportion is opposite to findings of other authors (Pevcin, 2012, Pryor, 2012). According 
to Marcuello (1998), the inversely related dependence between the wealth of a country and the size of the nonprofit sector occurs in the case of the so-called trust goods, where services of nonprofit institutions have a character of club goods, which are characterised by the nonrival nature of consumption (the consumption of the goods by one consumer does not decrease the available volume of the goods for other consumers), as well as the excludability from the consumption (in terms of costs, it is reasonably possible to exclude any consumer from the consumption!). On the other hand, a positive dependence between the wealth of a country and the size of the nonprofit sector was proved in less wealthy countries, which indicates a higher proportion of the so-called collective goods having the nature of truly public goods characterised by the typical non-excludability from the consumption.

Another possible explanation is that if the wealth of a country (measured by GDP per capita) grows, no new international nonprofit institutions enter the country and the old ones leave for more needed territories. For example, various American foundations do not operate primarily in the USA, but they accomplish their mission by distributing aid in poorer regions. In the 1990s, some of these foundations operated in the Czech Republic, then they gradually left for e.g. Romania and later to Africa. The transfer of some socially oriented non-profit institutions to developing regions and decreased need for establishing new ones can result in the reduction of the size of the nonprofit sector if GDP per capita is growing.

Individual and corporate volunteering can be another reason. Traditionally, inhabitants of wealthier countries (especially the Anglo-Saxon model) are used to direct involvement in welfare activities. They decide to participate in such activities voluntarily, formal organisation usually not being necessary. Individual voluntary activities do not have to be formally part of the nonprofit sector. All large companies develop a CSR (Corporate Social Responsibility) strategy. It includes the so-called corporate volunteering, in terms of which employees of companies develop welfare activities within the specified time bank. No specialised nonprofit institutions focussing on seniors need to be established, care can be provided directly by companies within their CSR strategy.

It was found out that the final consumption expenditure of nonprofit institutions serving households per capita is in direct proportion to the government expenditures on health care per capita in the relevant country, in direct proportion to the number of refugees per 100,000 inhabitants in the relevant country, and in direct proportion to the unemployment rate in the relevant country. In wealthier countries, the government failure theory has not been confirmed, i.e. that nonprofit institutions are a substitute for the government to some extent. With growing government expenditures on health care, the final consumption expenditure of nonprofit institutions serving households is growing on a long-term basis, which is contrary to the expectations of the authors. However, this can be explained by the complementarity of activities carried out by the government and by nonprofit institutions, where services of these sectors do not compete, but rather support and complement each other. Citizens establish nonprofit institutions if they feel there is a need for an offer, solving any urgent social problem (urgent demand for non-profit institutions). Such problems include unemployment on a long-term basis and, currently, the refugee crisis. 


\subsection{Less wealthy countries}

The economic model showed that the final consumption expenditure of nonprofit institutions serving households per capita is in direct proportion to GDP per capita in the relevant country, in inverse proportion to the age structure of inhabitants, in direct proportion to the share of inhabitants with completed tertiary education.

The different results in less wealthy countries compared to the group of wealthy countries (especially the different impact of GDP per capita) can be caused by the existing predominance of the funding of nonprofit activities from public resources. The reallocation of funds within the EU social policy also plays a role, when wealthier countries are usually net payers contributing to the EU budget, whereas less wealthy countries are the recipients of the funds from the EU budget. The budgets of the ministries, regions, towns and villages also directly contain the so-called institutions receiving contributions from the state budget, which are founded by the aforesaid public entities. The institutions receiving contributions manage the budget approved by their founders, who cover the operation of the institutions receiving contributions from the state budget with noninvestment contributions. In economically developed countries, the public legal form of institutions receiving contributions from the state budget is not very common. In those countries, the so-called subsidiarity is developing, where a public entity (e.g. local selfgovernment) initially expects the foundation initiative from citizens, and only then can it fund the new nonprofit institution via grants, which, however, a private nonprofit institution is not eligible to receive.

The group of less wealthy countries consists of European countries of the former Eastern Bloc. The older generation remembers fully public coverage of welfare services, including their central arrangement and prohibition to proceed differently. Its initiative corresponds to that. It is interesting to watch how deeply the former system affected the people living at that time. One should not blame only communism, but mainly the mentality of the middleaged and older generation for the current problems. Over decades, we believe, the attitude of citizens from wealthier and less wealthy (post-communist) countries will be similar. However, it is a generational issue.

A different concept of supporting socially disadvantaged people compared to wealthy and economically developed countries can be the reason why the inverse proportion between the size of the nonprofit sector serving households and the age structure of inhabitants was proved in less wealthy countries. In post-communist countries, seniors are supported by the social welfare system with their own efforts to save money for old age kept at a minimum. With the aging population, the needs of seniors are mostly covered from the state budget. Moreover, the state and/or regional self-governments establish senior care homes, which directly compete with nonprofit institutions dealing with care for the elderly. However, the state and regional self-governments are limited by the budget, and the offer of welfare services to seniors is therefore limited. Still, the excess demand is often not covered by nonprofit institutions, but by entities offering welfare services with the intention to make a profit. 
The model also indicates that the size of the nonprofit sector in less wealthy countries does not respond significantly to changes in the number of refugees (refugees usually head to wealthier countries), health care users and the unemployed. In less wealthy countries, health care and support of the unemployed is the role of government usually interfered only marginally by non-state nonprofit institutions.

The positive relationship between the size of the nonprofit sector and the share of inhabitants with tertiary education can be explained by the fact that an educated person can see the context better, can see the whole picture, tends to be more active, and shows interest in nonprofit activities more often.

\section{Conclusion}

The aim of the article was to identify the determinants of the size of the nonprofit sector serving households, to determine the direction and intensity of their influence on the size of the nonprofit sector serving households in OECD countries. Based on the econometric modelling of panel data from 39 OECD countries, authors identified different socioeconomic determinants of the nonprofit sector in the group of wealthier countries compared to the group of less wealthy countries. Results can be generalized only for nonprofit sector serving households and OECD countries. Analysis did not cover low-income developing countries which often do not have enough quality data for proper econometric analysis.

Higher wealth of the country measured by GDP per capita positively affects the size of the nonprofit sector serving households in the group in less wealthy countries (mostly former Eastern Bloc countries). Alternatively, it adversely affects the dimension of the nonprofit sector serving households in wealthier countries which goes against previous research (Pevcin, 2012; Pryor, 2012). Authors found the cause in the different role of the government and different approach to fundraising between the two groups of countries. While there is a persistent dominance of funding nonprofit activities from public budget in the less wealthy countries (thus increasing country's wealth creates favourable conditions for the emergence of nonprofit organizations), the nonprofit institutions in the wealthier countries rather seek private donors. Moreover, the NGOs move from wealthy countries into the more needed territories.

Previous studies indicated that inversely related dependence between the country's wealth and the size of the nonprofit sector occurs in the case of club goods which are characterised by the non-rival nature of consumption and excludability from the consumption. On the other hand, a positive dependence in less wealthy countries suggests a higher proportion of collective goods having the nature of truly public goods characterised by the typical non-excludability from the consumption.

The size of nonprofit sector also depends on whether the support and services provided by the government are substitutes or complements to the services provided by nonprofit organizations. In the wealthier countries, the government health care competes with nonprofits since the government support has been substituted by the nonprofit sector. Conversely, the nonprofit sector plays a vital role during social crises when the number of refugees and the unemployed people increases. In the less wealthy countries, 
a dimension of the nonprofit sector does not respond significantly to changes in the number of refugees, users of health care and the unemployed, but it responds to the age structure of the population. With the aging population, the needs of seniors are mostly covered from the state budget. Moreover, government and/or regional self-governments establish senior care homes, which directly compete with nonprofit institutions dealing with care for the elderly. The government thus reduces the space for nonprofit organizations that also provide services for seniors. So, the demand for social services is often provided by commercial entities.

One of the opportunity for further research could be a confirmation of the theory by Carmen Marcuello (1998). The theory declares that the effect of the country's wealth to the size of the nonprofit sector serving households depends on the structure of the activities of the nonprofits regarding the non-rivalry and non-excludability of consumers from using the services of nonprofit organizations. The results suggest that there are differences between the wealthier and less wealthy countries but the theory must be empirically proven. 


\begin{tabular}{|c|c|c|c|c|c|}
\hline 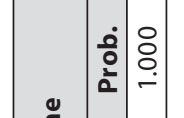 & s? & 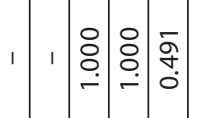 & 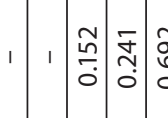 & : & $\frac{8}{2}=\sqrt{2}=5$ \\
\hline 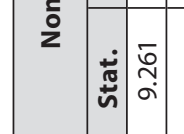 & 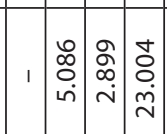 & 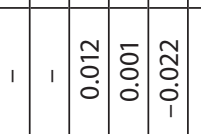 & & 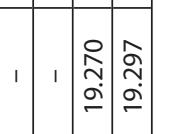 & 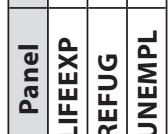 \\
\hline 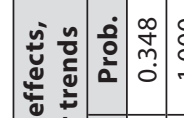 & : & 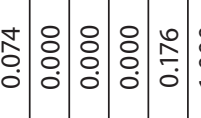 & $=0$ & 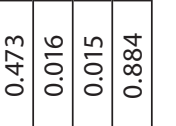 & $\frac{8}{2}=\underline{E} \equiv$ \\
\hline 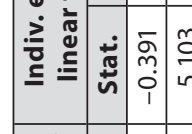 & 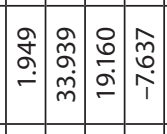 & 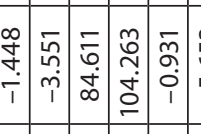 & & 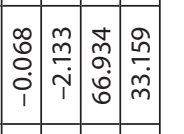 & 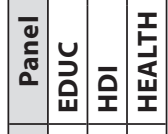 \\
\hline 密 & 혛영혛 & 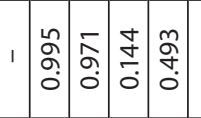 & 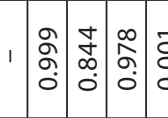 & 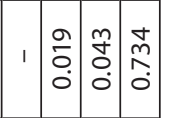 & $\dot{z} \equiv \equiv \equiv$ \\
\hline 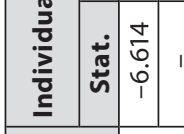 & 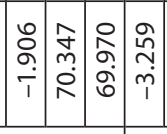 & 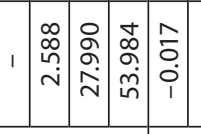 & & 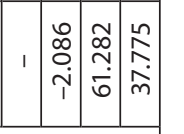 & مَّة \\
\hline & HH & dxastin & & wno & \\
\hline 常: & 횡용 & 웜웜욤 & & 잉 & 월 \\
\hline 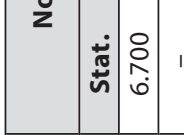 & 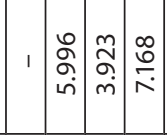 & 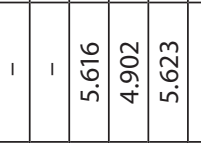 & 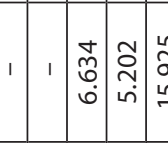 & 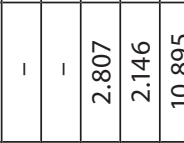 & 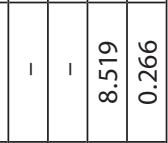 \\
\hline 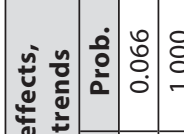 & 篔愛。 & 옿 & ㅎํㅇ용영 & ํํํํํํํํํำ & :영: \\
\hline 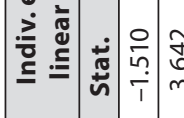 & 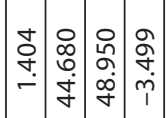 & $\frac{9}{20} 80$ & 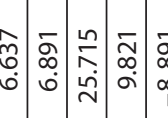 & 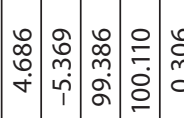 & $\frac{\mathfrak{m}}{9}=$ \\
\hline 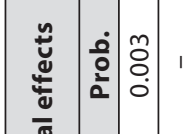 & 商絪高 & 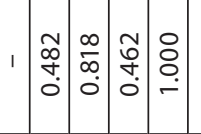 & 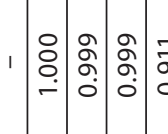 & 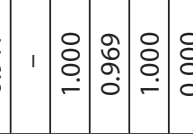 & \\
\hline 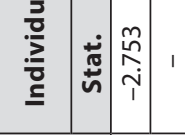 & 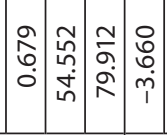 & 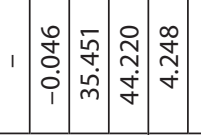 & 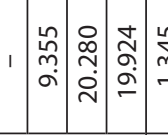 & 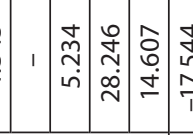 & 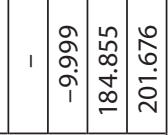 \\
\hline$:$ & 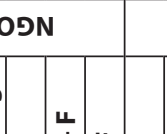 & & & nas & \\
\hline
\end{tabular}




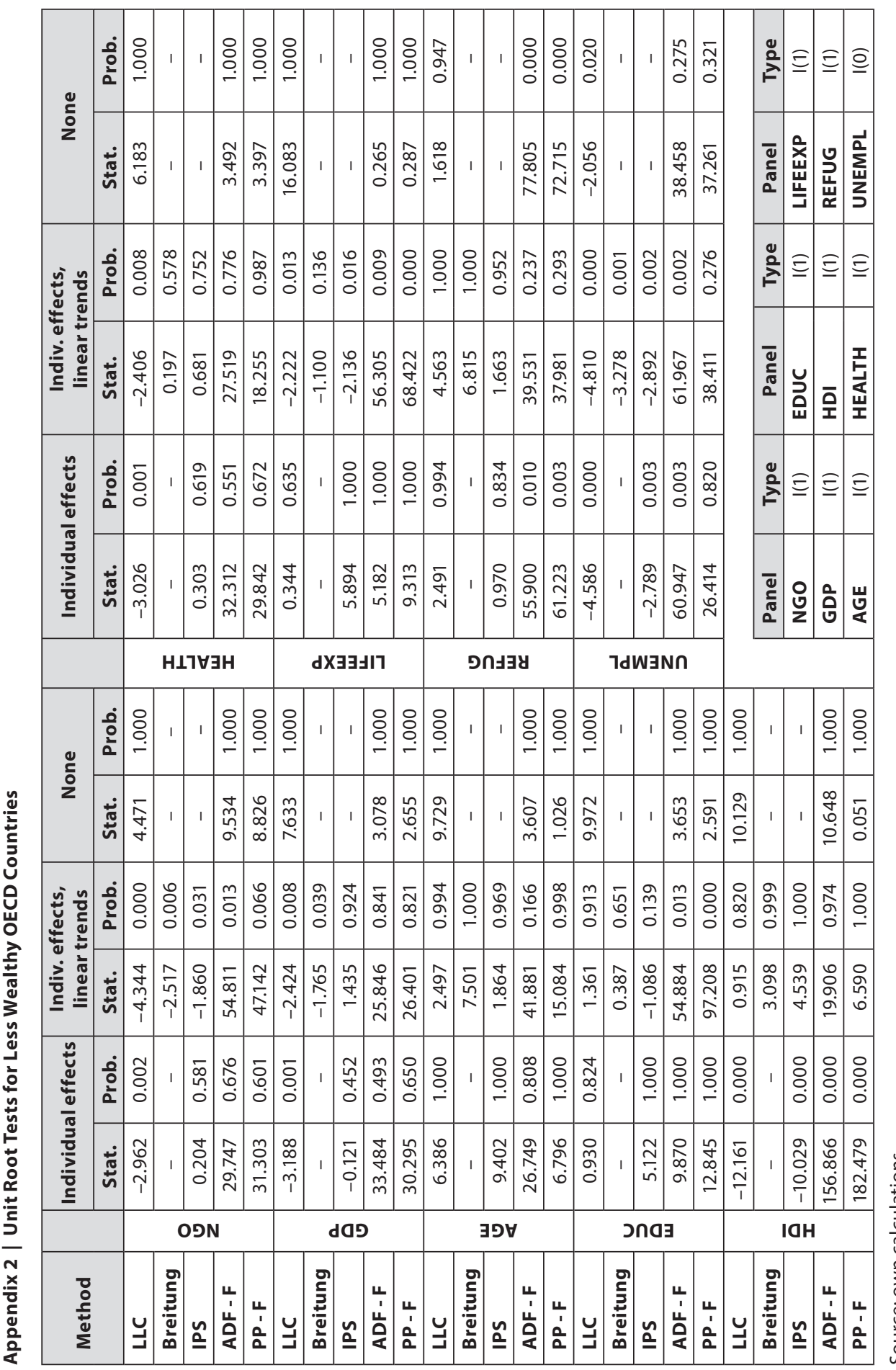




\section{References}

Arlt, J., Arltová, M. (2005). Vztah deficitu běžného účtu platební bilance a rozpočtového deficitu - analýza panelových dat. (The Relationship of Budget Deficit and Current Account Balance - Panel Data Analysis.) Politická ekonomie, 53(6), 747-764, https://doi.org/10.18267/j.polek.535

Baltagi, B. H., Fomby, T. B., Hill, R. C. (eds.) (2000). Nonstationary Panels, Panel Cointegration, and Dynamic Panels. Advances in Econometrics, Vol. 15, Amsterdam: Elsevier Science.

Ben-Ner, A., van Hoomissen, T. (1991). Nonprofit Organisations in the Mixed Economy: a Demand and Supply Analysis. Annals of Public and Cooperative Economics, 62(4), 519-550.

Breitung, J. (2000). The Local Power of Some Unit Root Tests for Panel Data, in Baltagi, B., ed., Advances in Econometrics, Vol. 15: Nonstationary Panels, Panel Cointegration, and Dynamic Panels. Amsterdam: JAI Press, pp. 161-178.

Clerkin, R. M., Swiss, J. E. (2013). Religious Motivations and Social Service Volunteers: The Interaction of Differing Religious Motivations, Satisfaction, and Repeat Volunteering. Interdisciplinary Journal of Research on Religion, 9(11), 1-19.

EC (2013). European Systems of Accounts 2010. Luxembourg: Publications Office of the European Union. Available at: http://ec.europa.eu/eurostat/web/ products-manuals-and-guidelines/-/KS-02-13-269

Gazley, B. (2010). Linking Collaborative Capacity to Performance Measurement in Government Nonprofit Partnerships. Nonprofit and Voluntary Sector Quarterly, 39(4), 653-673, https://doi.org/10.1177/0899764009360823

Gazley, B., Brudney, J. L. (2007). The Purpose (and Perils) of Government-nonprofit Partnership. Nonprofit and Voluntary Sector Quarterly, 36(3), 389-415, https://doi. org/10.1177/0899764006295997

Gil-Lacruz, A., Marcuello, C. (2013). Voluntary Work in Europe: Comparative Analysis among Countries and Welfare Systems. Social Indicators Research, 114(2), 371-382, https://doi. org/10.1007/s11205-012-0150-5

Gonzalez, L. I. A., Vijande, M. L. S., Casielles, R. V. (2002). The Market Orientation Concept in the Private Nonprofit Organization Domain. International Journal of Nonprofit and Voluntary Sector Marketing, 7(1), 55-67, https://doi.org/10.1002/nvsm.167

Grønbjerg, K. A., Paarlberg, L. (2001). Community Variations in the Size and Scope of the Nonprofit Sector: Theory and Preliminary Findings. Nonprofit and Voluntary Sector Quarterly, 30(4), 684-706, https://doi.org/10.1177/0899764001304004

Hansmann, H. (1987). Economic Theories of Nonprofit Organization, in Powell, W.W., ed., The Nonprofit Sector: A Research Handbook. New Haven, CT: Yale University Press, pp. 27-42.

Im, K. S., Pesaran, M. H., Shin, Y. (2003). Testing for Unit Roots in Heterogeneous Panels. Journal of Econometrics, 115(1), 53-74, https://doi.org/10.1016/s0304-4076(03)00092-7

Jesse, D., Lecy, J. D., van Slyke, D. M. (2013). Nonprofit Sector Growth and Density: Testing Theories of Government Support. Journal of Public Administration Research Theory, 23(1), 189-214, https://doi.org/10.1093/jopart/mus010

Kao, C. (1999). Spurious Regression and Residual-based Tests for Cointegration in Panel Data. Journal of Econometrics, 90(1), 1-44, https://doi.org/10.1016/s0304-4076(98)00023-2

Levin, A., Lin, C. F. (1992). Unit Root Test in Panel Data: Asymptotic and Finite Sample Properties. University of California at San Diego. Discussion Paper 92-93. 
Levin, A., Lin, C. F., Chu, C. (2002). Unit Root Tests in Panel Data: Asymptotic and FiniteSample Properties. Journal of Econometrics, 108(1), 1-24, https://doi.org/10.1016/ s0304-4076(01)00098-7

Luksetich, W. (2008). Government Funding and Nonprofit Organizations. Nonprofit and Voluntary Sector Quarterly, 37(3), 434-442, https://doi.org/10.1177/0899764007310415

Maddala, G. S., Wu, S. (1999). A Comparative Study of Unit Root Tests with Panel Data and A New Simple Test. Oxford Bulletin of Economics and Statistics, 61(S1), 631-652, https://doi.org/10.1111/1468-0084.0610s1631

Marcuello, C. (1998). Determinants of the Nonprofit Sector Size: An Empirical Analysis in Spain. Annals of Public and Cooperative Economics, 69(2), 175-192, https://doi. org/10.1111/1467-8292.00078

Matsunaga, Y., Yamauchi, N., Okuyama, N. (2010). What Determines the Size of the Nonprofit Sector? A Cross-country Analysis of the Government Failure Theory. Voluntas, 21(2), 180-201, https://doi.org/10.1007/s11266-010-9125-9

O'Regan, K., Oster, S. (2002). Does Government Funding Alter Nonprofit Governance? Evidence from New York City Nonprofit Contractors. Journal of Policy Analysis and Management, 21(3), 359-379, https://doi.org/10.1002/pam.10050

OECD (2016). OECD. Stat. Statistical database. Paris: Organisation for Economic Co-operation and Development. Available at: http://stats.oecd.org/

Pesaran, M. H. (2015). Time Series and Panel Data Econometrics. Oxford: Oxford University Press. ISBN 978-01-987-3691-2.

Pestoff, V. A. (1992). Third Sector and Co-operative Services. From Determination to Privatization. Journal of Consumer Policy, 15(1), 21-45, https://doi.org/10.1007/bf01016352

Pevcin, P. (2012). Analysis of Cross-Country Differences in the Nonprofit Sector Size. Prague Economic Papers, 21(2), 186-204, https://doi.org/10.18267/j.pep.418

Phillips, P. C. B., Moon, H. (1999). Linear Regression Limit Theory for Nonstationary Panel Data. Econometrica, 67(5), 1057-1111, https://doi.org/10.1111/1468-0262.00070

Phillips, P. C. B., Moon, H. (2000). Nonstationary Panel Data Analysis: an Overview of Some Recent Developments. Econometric Reviews, 19(3), 263-286, https://doi. org/10.1080/07474930008800473

Pryor, F. L. (2012). Determinants of the Size of the Nonprofit Sector. The European Journal of Comparative Economics, 9(3), 337-348.

Roland, A. B., Valentinov, V., Buchenrieder, G. (2010). Nonprofit Extension in Rural Cameroon: A Study of Demand and Supply Determinants. International Journal of Social Economics, 37(5), 391-399, https://doi.org/10.1108/03068291011038972

Salamon, L. M., Sokolowski, S. W., Anheier, H. K. (2000). Social Origins of Civil Society: An Overview. Working Papers of the Johns Hopkins Comparative Nonprofit Sector Project.

Schwenger, D., Straub, T., Borzillo, S. (2014). Non-governmental Organizations: Strategic Management for a Competitive World. The Journal of Business Strategy, 35(4), 11-19, https://doi.org/10.1108/jbs-11-2013-0105

Steinberg, R. (2006). Economic Theories of Nonprofit Organizations, in Powel, W.W., Steinberg, R., eds., The Nonprofit Sector: A Research Handbook. 2nd ed., New Haven, CT: Yale University, pp. 117-139.

UNDP (2016). United Nations Development Programme. Available at: http://www.undp.org 
Valentinov, V. (2008). The Economics of Nonprofit Organization: In Search of an Integrative Theory. Journal of Economic Issues, 42(3), 745-761, https://doi.org/10.1080/00213624.200 8.11507177

Valentinov, V. (2009). Managerial Nonpecuniary Preferences in the Market Failure Theories of Nonprofit Organization. International Journal of Social Economics, 36(1/2), 81-92, https://doi.org/10.1108/03068290910921208

WB (2016). World Bank Open Data. The World Bank. Available at: http://databank.worldbank. org/data/home.aspx

Weinblatt, J. (1992). Do Government Transfers Crowd Out Private Transfers to Nonprofit Organizations? The Israeli Experience. International Journal of Social Economics, 19(2), 60-66, https://doi.org/10.1108/eum0000000000482

WHO (2016). Global Health Observatory (GHO) data. World Health Organisation. Available at: http://www.who.int/gho/database/en 